\title{
The quest for sustainable nitrogen removal technologies
}

\author{
A. Mulder \\ Amecon Environmental Consultancy, P.O. Box 606, 2600 AP Delft, The Netherlands \\ (E-mail: arnoldmulder@amecon.n!)
}

\begin{abstract}
In this paper the sustainability of current available and future nitrogen removal systems has been investigated. For the assessment of the sustainability six indicators were used; sludge production; energy consumption, resource recovery; area requirement and $\mathrm{N}_{2} \mathrm{O}$-emission. For the evaluation of the position of the individual nitrogen removal systems in the anthropogenic nitrogen cycle a broad outline for a life-cycle analysis has been presented.
\end{abstract}

Keywords Algal ponds; Anammox; constructed wetlands; denitrification; duckweed ponds; life-cycle analysis (LCA); nitrification; nitrogen cycle; resource recovery; sustainable processes; wastewater treatment

\section{Introduction}

For human life and health a diet with sufficient protein is essential. This results in a central position of man in the anthropogenic nitrogen cycle (Figure 1). The supply of protein food for the global population by agriculture is nowadays largely dependent on the use of synthetic nitrogen fertiliser produced from atmospheric $\mathrm{N}_{2}$ by the Haber-Bosch process. In the last century the world's annual industrial output of nitrogenous fertiliser increased from $10 \mathrm{Mt} \mathrm{N}$ in 1960 to about $90 \mathrm{Mt} \mathrm{N}$ in 1998 (Figure 2). The global estimate for biological nitrogen fixation is in the range of 200-240 Mt N which shows that the anthropogenic mass flows for nitrogen have a major impact on the global nitrogen cycle (Gijzen and Mulder, 2001). However, the consumption of proteins will ultimately result in the discharge of the protein nitrogen in wastewater (Figure 1).

In view of the substantial contribution of the inorganic nitrogen in wastewater in the global nitrogen balance it is relevant to consider the sustainability of the current available nitrogen removal and cycling processes. The processes and technologies that will be considered in this paper are physical-chemical processes, conventional and advanced nitrification and denitrification in activated sludge systems, algal ponds, duckweed ponds and constructed wetlands. This paper presents further a framework to assess the sustainability of the individual processes and technologies. The process properties and criteria which have been evaluated are energy consumption in relation to the total nitrogen cycle, area requirement, process stability, sludge production, global or regional applicability, $\mathrm{N}_{2} \mathrm{O}$ emission and resource recovery. Further, the aspect of dilution of sewage in the widely applied flush toilet will be discussed.

\section{Indicators for sustainable nitrogen removal}

For the assessment of the sustainability of wastewater treatment systems for N-removal in this study the following indicators have been used: sludge production; energy consumption; resource recovery; area requirement and emission of nitrous oxide $\left(\mathrm{N}_{2} \mathrm{O}\right)$. In the literature there is general agreement on the relevance of minimising sludge production and maximising resource recovery for sustainability of treatment systems (Henze, 1997; Roeleveld et al., 1997; Van der Graaf et al., 1997). However with respect to energy consumption some authors conclude that the contribution of wastewater treatment in the total energy consumption is relatively low and therefore minimisation of the energy demand was 
considered to be less relevant (Roeleveld et al., 1997). However in this study the energy consumption for nitrogen removal is compared with the energy input in the total nitrogen cycle. For the assessment of the environmental impact of the alternative nitrogen removal processes a life-cycle analysis (LCA) has been made for the anthropogenic $\mathrm{N}$-cycle. When the sustainability of total nitrogen cycle is discussed the aspect of dilution will be included.

\section{Anthropogenic nitrogen balance}

For a concise life-cycle analysis of the anthropogenic use of reactive nitrogen, the input and ultimate human output of nitrogen have been compared. At the end of the twentieth century the global annual input of nitrogen fertiliser in the human food chain was about $15 \mathrm{~kg} \mathrm{~N}$ per capita (Figure 3). A fraction of this nitrogen will be incorporated in vegetable or animal protein. The amount of protein in the human diet varies world-wide from 20 to more then $100 \mathrm{~g}$ protein per head daily. After human consumption ultimately a large fraction of the protein nitrogen will be excreted. Based on a nitrogen content in protein of 6.25 the daily human discharge is estimated at 5 to $16 \mathrm{~g}$ nitrogen per head per day. This is in agreement with reported typical values for human nitrogen excretion (Table 1).

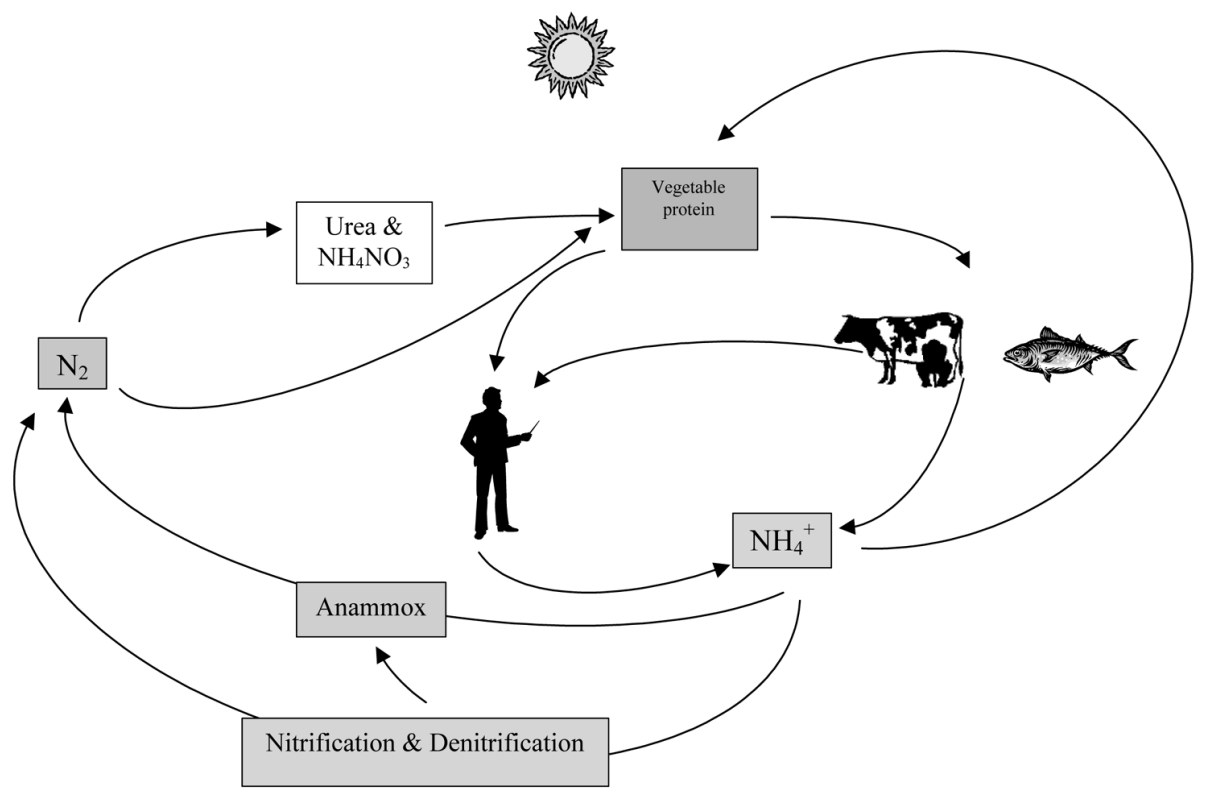

Figure 1 The anthropogenic nitrogen cycle

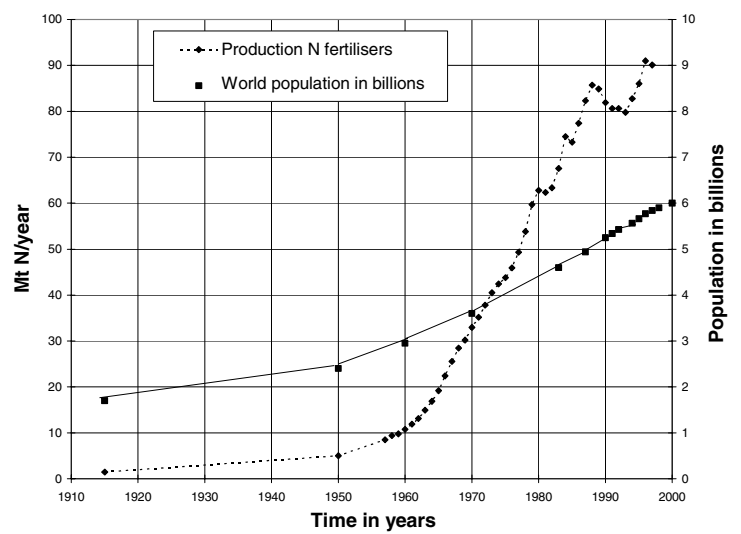




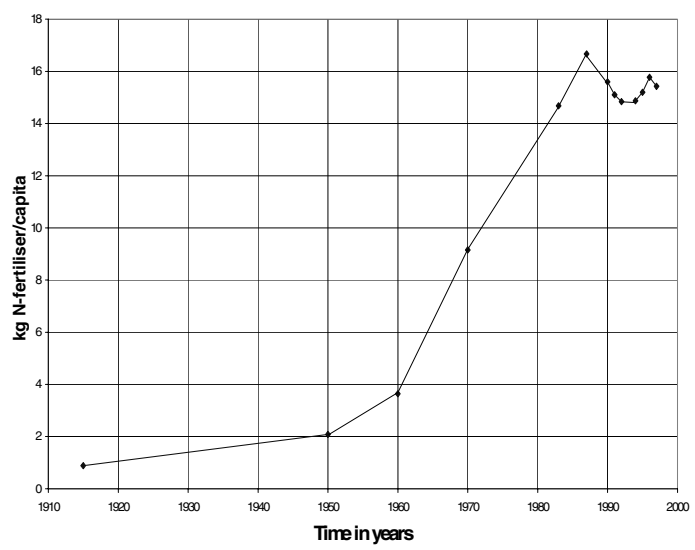

Figure 3 Development in the global annual production of nitrogen fertiliser per capita

Based on an average excretion of $13 \mathrm{~g} \mathrm{~N}$ per capita per day the annual excretion is 4.75 $\mathrm{kg} \mathrm{N}$ per capita. Comparison of the global averages for input and output of $\mathrm{N}$ in the human food chain show that about 30\% fertiliser nitrogen ends up in wastewater (Figure 4). However for Norway and The Netherlands the balance of fertiliser nitrogen input and human output through wastewater differ considerably from the global average (Figure 4). This confirms the presence of regional imbalances (Laegreid et al., 1999).

In countries with intensive agriculture and factory farming (Norway and The Netherlands) only about $18 \%$ of the fertiliser nitrogen will end up in the wastewater. This means that in these European countries in theory with full nitrogen recovery from wastewater the agricultural demand for $\mathrm{N}$-fertiliser can be met for only $18 \%$. Due to the input of other sources such as imported cattle feed, wet and dry deposition and biological

Table 1 Typical values human nitrogen excretion

\begin{tabular}{cccc}
\hline Faeces (g N/Capita.d) & Urine (g N/Capita.d) & Total (g N/Capita.d) & Reference \\
\hline $1.8-4.9$ & $7.5-13.3$ & $9.3-18.2$ & Gootaas, 1956 \\
1.5 & 12.2 & 13.7 & Pöpel, 1993 \\
- & $9.2-13.8$ & - & Larsen and Guyer, 1996 \\
\hline
\end{tabular}

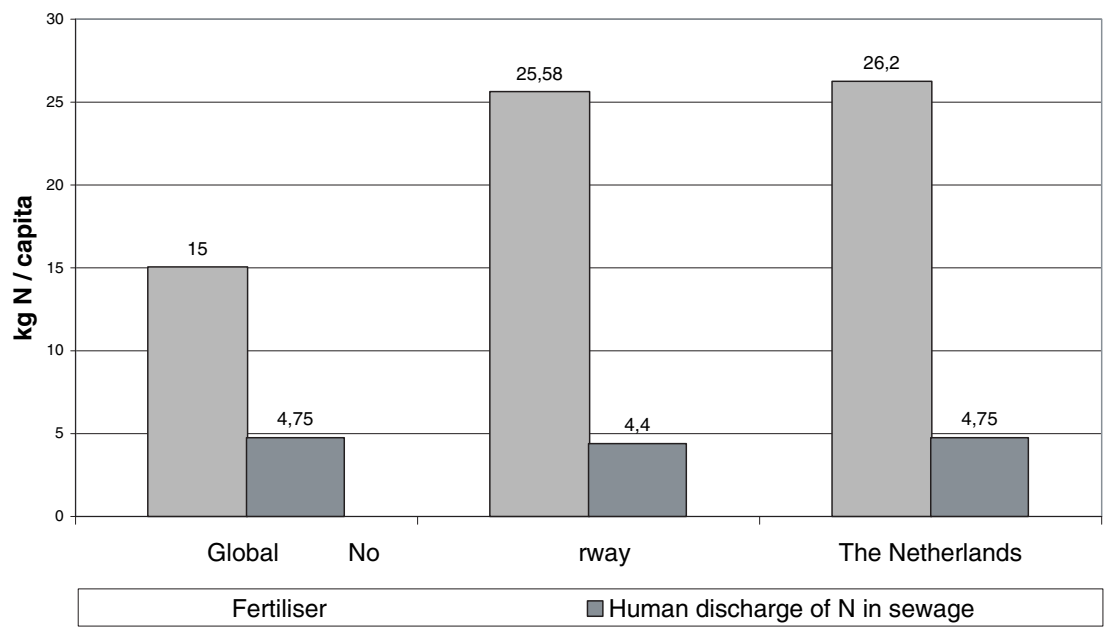

Figure 4 Comparison of the annual balance of $\mathrm{N}$-fertiliser use and human $\mathrm{N}$-discharge on global scale and on national scale in Norway (Bleken and Bakken, 1997) and The Netherlands (RIVM, 1991) 
fixation, the contribution of anthropogenic nitrogen output via sewage in the total $\mathrm{N}$-input is actually only about $10 \%$ (Bleken and Bakken, 1997). Measures aimed at an increase of the efficiency in the nitrogen cycle, such as the development of slow release fertilisers and improving the conversion efficiency in cattle feed are therefore considered to be more effective compared with resource recovery from sewage (Bleken and Bakken, 1997). On the other hand there will be regions with insufficient $\mathrm{N}$-input where the contribution of $\mathrm{N}$ recovery from sewage can be a relevant factor. This is in agreement with the suggestion of Larsen and Guyer (1996) to apply separate management of anthropogenic nutrient solutions in nutrient demanding nations.

\section{Survey of nitrogen removal systems for wastewater}

Wastewater concentration as factor in the selection of an optimal $\mathrm{N}$-removal system

For the removal of ammonium from wastewater a wide variety of biological and physicochemical removal systems are available (Henze et al., 1996; Priestley et al., 1995). For a specific application the available alternatives will be evaluated on cost aspects, chemical and energy requirements, operational experience and process reliability. The selection of the most optimal alternative is generally based on cost-effectiveness. However in practice the selection of either a biological or a physicochemical method is determined by the nitrogen concentration of the wastewater. Three concentration ranges can be distinguished:

1. Diluted wastewater with an ammonium concentration $<0.1 \mathrm{~kg} \mathrm{~N} / \mathrm{m}^{3}$. In this range biological N-removal is the preferred process based on cost-effectiveness. Domestic wastewater is within this range.

2. Concentrated wastewater with ammonium concentrations in the range $0.1-5 \mathrm{~kg} \mathrm{~N} / \mathrm{m}^{3}$. A typical example is sludge liquor for which after extensive investigations biological treatment was preferred (Janus et al., 1997). Although ammonia stripping and producing $\mathrm{MgNH}_{4} \mathrm{PO}_{4}$ were identified as interesting alternatives for resource recovery these options were not cost-effective (Priestley et al., 1995; Janus et al., 1997).

3. Concentrated wastewater with ammonium concentrations $>5 \mathrm{~kg} \mathrm{~N} / \mathrm{m}^{3}$. In this range physicochemical methods are technically and economically feasible. A successful example is the steam stripping of a wastewater with an ammonium concentration of $1.5 \%$ followed by ammonia recovery which has been in operation on industrial scale since 1985 (Harmsen et al., 1986).

The concentration of wastewater is generally $<2 \mathrm{~kg} \mathrm{~N} / \mathrm{m}^{3}$ thus biological treatment systems are preferred.

\section{Survey of biological $\mathbf{N}$-removal systems}

For the biological N-removal systems which are investigated in this study the typical values of specific operational parameters are summarized in Table 2. The following N-removal systems are considered:

- Activated sludge with conventional nitrification and denitrification. Around the world the activated sludge system with nitrification and denitrification is the most widely used system for $\mathrm{N}$-removal with many design variations (Henze et al., 1996). In the nitrification process ammonium is via nitrite converted into nitrate: $\mathrm{NH}_{4}{ }^{+}+2 \mathrm{O}_{2} \rightarrow \mathrm{NO}_{3}{ }^{-}+2 \mathrm{H}^{+}$ $+\mathrm{H}_{2} \mathrm{O}$. According to this reaction the oxidation of $1 \mathrm{~kg} \mathrm{~N}$ requires $4.57 \mathrm{~kg} \mathrm{O}_{2}$. For denitrification the required $\mathrm{COD} / \mathrm{N}$ ratio varies from 3-6.

- Activated sludge with nitrification denitrification via nitrite. In this process ammonium is oxidised into nitrite: $2 \mathrm{NH}_{4}{ }^{+}+3 \mathrm{O}_{2} \rightarrow 2 \mathrm{NO}_{2}{ }^{-}+4 \mathrm{H}^{+}+2 \mathrm{H}_{2} \mathrm{O}$. The oxidation of $1 \mathrm{~kg} \mathrm{~N}$ requires $3.42 \mathrm{~kg} \mathrm{O}_{2}$. Under anaerobic conditions nitrite is reduced into nitrogen gas and the required $\mathrm{COD} / \mathrm{N}$ ratio is $2-4$.

- Activated sludge with autotrophic N-removal. Recently the Anammox process in which 
ammonium is oxidised under anaerobic conditions was discovered by serendipity (Mulder et al., 1995). This process can be considered as an advanced biological nitrogen removal process in which nitrification and denitrification are integrated. Initially it was unknown whether nitrite or nitrate was used as electron donor however later it was found that in the Anammox process ammonium and nitrite are reacting and release nitrogen gas into the N-cycle (Strous, 2000). First ammonium must be oxidised to nitrite and then with Anammox the overall reaction of the autotrophic nitrogen removal process is: $4 \mathrm{NH}_{4}{ }^{+}+3 \mathrm{O}_{2} \rightarrow 2 \mathrm{~N}_{2}$. According to this reaction the removal of $1 \mathrm{~kg} \mathrm{~N}$ requires $1.71 \mathrm{~kg}$ $\mathrm{O}_{2}$.

- Algal ponds. In algal ponds ammonia is assimilated into algal biomass according to the equation: $\mathrm{NH}_{3}+5 \mathrm{CO}_{2}+2 \mathrm{H}_{2} \mathrm{O} \rightarrow \mathrm{C}_{5} \mathrm{H}_{7} \mathrm{O}_{2} \mathrm{~N}+5 \mathrm{O}_{2}$. The energy use in the algal pond is required for mixing and pumping. The highest value of the $\mathrm{N}$-load is corresponding with the lowest efficiency.

- Duckweed ponds. From the applied N-load 41-68\% is assimilated in duckweed (Alaerts et al., 1996).

- Constructed wetlands. In constructed wetlands biomass is not recovered. The highest value of the $\mathrm{N}$-load corresponds with the lowest removal efficiency.

Table 2 Typical values of specific operational parameters of biological N-removal systems

\begin{tabular}{|c|c|c|c|c|c|c|}
\hline $\mathrm{N}$-removal system & $\begin{array}{c}\text { N-load } \\
\text { (kg N/ ha.d) }\end{array}$ & $\begin{array}{c}\text { Energy } \\
\text { consumption } \\
(\mathbf{k W h} / \mathbf{k g ~ N})\end{array}$ & $\begin{array}{l}\text { COD/ } \\
\text { N-ratio }\end{array}$ & $\begin{array}{c}\text { Sludge/biomass } \\
\text { production } \\
(\mathbf{k g ~ d . w . / k g ~ N})^{1)}\end{array}$ & $\begin{array}{c}\mathrm{N}_{\text {total }} \\
\text { removal } \\
\text { efficiency (\%) }\end{array}$ & $\begin{array}{l}\text { Comments and } \\
\text { references }\end{array}$ \\
\hline $\begin{array}{l}\text { Activated sludge } \\
\text { conventional } \\
\text { nitrification- } \\
\text { denitrification }\end{array}$ & $200-700^{2)}$ & $2.3^{3)}$ & $3-6$ & $1-1.2$ & $>75$ & $\begin{array}{l}\text { Based on plants } \\
\text { with typical load } \\
\text { of } 0,05-0,1 \\
\text { kg BOD/ kg d.w.d. } \\
\text { Henze et al., } 1996\end{array}$ \\
\hline $\begin{array}{l}\text { Activated sludge } \\
\text { nitrification- } \\
\text { denitrification } \\
\text { via nitrite }\end{array}$ & $200-700^{21}$ & $1.7^{3)}$ & $2-4$ & $0.8-0.9$ & $>75$ & $\begin{array}{c}\text { Abeling and } \\
\text { Seyfried, 1992; } \\
\text { Balmelle et al., } 1992\end{array}$ \\
\hline $\begin{array}{l}\text { Activated sludge } \\
\text { autotrophic } \\
\text { N-removal }\end{array}$ & $>200-700^{2)}$ & 0.9 & 0 & $<0.1$ & $>75$ & $\begin{array}{c}\text { Feasibility } \\
\text { demonstrated for } \\
\text { concentrated wastewater. } \\
\text { Mulder, 1995; } \\
\text { Seyfried et al., } 2002\end{array}$ \\
\hline Algal pond & $15-30$ & $0.1-1$ & $6-7$ & $10-15$ & $23-78$ & $\begin{array}{c}\text { El Hamouri et al., } \\
\text { 1995; Oswald, } \\
\text { 1995; Polprasert, } 1996\end{array}$ \\
\hline Duckweed pond & $3-4$ & $<0.1$ & 28 & $20-26$ & $74-77$ & $\begin{array}{l}\text { System operated } \\
\text { at } 17-33^{\circ} \mathrm{C} . \\
\text { Alaerts et al., } 1996\end{array}$ \\
\hline Constructed wetland & d $3-26^{4)}$ & $<0.1$ & $2-7$ & - & $30-70$ & $\begin{array}{c}\text { Hammer and Knight } \\
\text { 1994; Haberl, 1995; } \\
\text { Wittgren and Tobiason, } \\
\text { 1995; Meuleman, } 1999\end{array}$ \\
\hline
\end{tabular}

1. d. w. = dry weight

2. Calculated based on a conservative value of the aeration tank depth of $2 \mathrm{~m}$ and surface area aeration tank is $25 \%$ of total plant area

3. The given values are energy required for aeration and are exclusive energy in COD used for denitrification. Aeration efficiency is $2 \mathrm{~kg} \mathrm{O}_{2} / \mathrm{kWh}$

4. An exceptional high load of $112 \mathrm{~kg} \mathrm{~N} /$ ha.d was reported by Van Oostrom (1995) 


\section{Assessment of the sustainability of $\mathrm{N}$-removal systems}

\section{Energy use for $\mathrm{N}$-fixation and $\mathrm{N}$-removal}

The energy use of the alternative N-removal processes has been compared with of the energy use for $\mathrm{N}$-fertiliser production (Figure 5). In the Haber-Bosch process nitrogen fixation with natural gas proceeds according to the equation: $3 \mathrm{CH}_{4}+4 \mathrm{~N}_{2}+6 \mathrm{H}_{2} \mathrm{O} \rightarrow 3 \mathrm{CO}_{2}$ $+8 \mathrm{NH}_{3}$. For the currently applied $\mathrm{N}$-fertiliser production processes the energy use is $44.5 \mathrm{MJ} / \mathrm{kg} \mathrm{N}$ which can be reduced to $34.5 \mathrm{MJ} / \mathrm{kg} \mathrm{N}$ in production plants where best available technology is applied (Laegreid et al., 1999). The energy required for nitrification was calculated from the data given in Table 2. The energy used for denitrification was calculated from the required COD. When resource recovery is applied the production of $\mathrm{N}$-fertiliser will require an equivalent reduced amount of energy. The obtained results show that for conventional nitrification-denitrification the energy consumption for $\mathrm{N}$-removal is 42.2 $\mathrm{MJ} / \mathrm{kg} \mathrm{N}$. This is nearly similar with the energy use for $\mathrm{N}$-fertiliser production. The energy required in the autotrophic $\mathrm{N}$-removal process is $3.1 \mathrm{MJ} / \mathrm{kg} \mathrm{N}$ which is only $7 \%$ of the energy required in the conventional process. By application of resource recovery the situation becomes more favorable, however it must considered that the recovery and processing of the nitrogen from urine will require energy.

\section{Recovery of reactive nitrogen versus denitrification}

From the biological N-removal systems only the algal and duckweed pond system apply resource recovery, by using the produced algae and duckweed respectively. In the activated sludge systems the ammonium nitrogen is recycled as nitrogen gas. Direct recovery of ammonium from human wastewater is only feasible when the flush toilet and the collection and transport system for urine are modified fundamentally (Stoner, 1977; Larsen and Guyer, 1996). For the assessment of the environmental advantage of the resource recovery for nitrogen the energy use for $\mathrm{N}$-fertiliser production has been compared with the energy use of the alternative N-removal processes (Figure 5). The energy use of the autotrophic Nremoval process and the $20 \%$ resource recovery will come on a similar level after addition of the energy used for recovery.

\section{Sludge production}

The autotrophic N-removal process has lowest sludge production (Table 2).

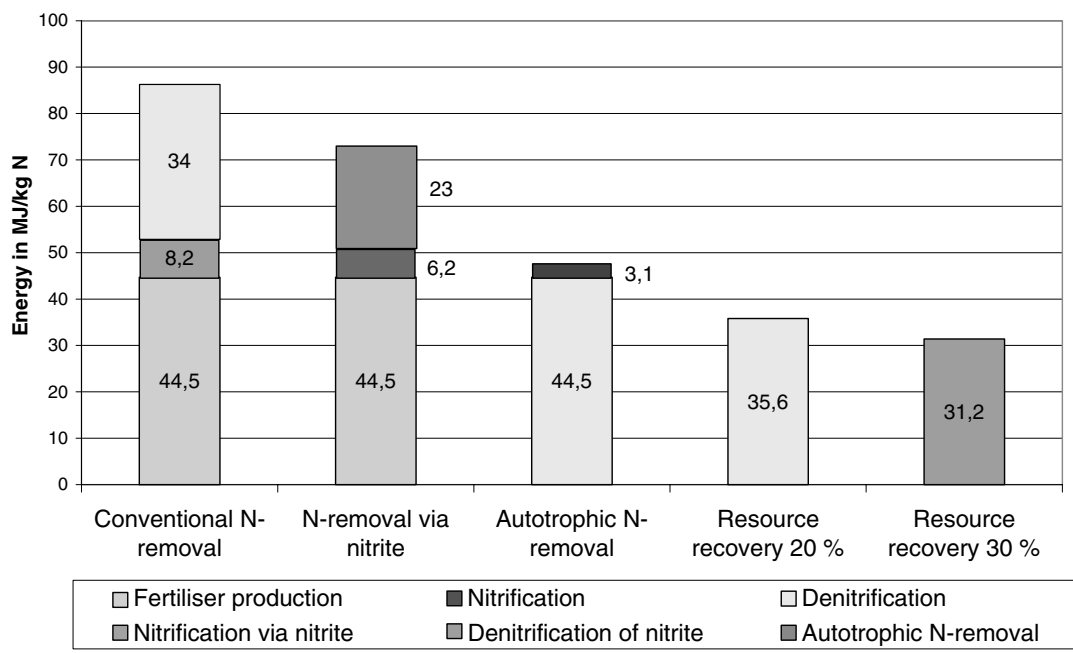

Figure 5 Comparison of the energy use for $\mathrm{N}$-fertiliser production with the energy use of the alternative $\mathrm{N}$ - 


\section{Area requirement}

For the individual N-removal systems the N-load, as measured for the area requirement, differs considerably (Table 2 and Figure 6). The wide range for the activated sludge systems is caused by differences in plant size. The average value of $450 \mathrm{~kg} \mathrm{~N} / \mathrm{ha} . \mathrm{d}$ is a factor 30-150 higher then for respectively the algal and duckweed pond systems. The higher loading rates are the result of faster biological processes which are possible due to the aeration. However because of this the energy use for the activated sludge systems is higher (Figure 6). In systems with the autotrophic N-removal process the energy use is reduced at similar N-load (Figure 6).

\section{Emission of $\mathrm{N}_{\mathbf{2}} \mathrm{O}$ in the anthropogenic nitrogen cycle}

At different stages of the anthropogenic nitrogen cycle emission of $\mathrm{N}_{2} \mathrm{O}$ occurs. The global anthropogenic emission of $\mathrm{N}_{2} \mathrm{O}$ is estimated at about $3 \mathrm{M}$ ton $\mathrm{N}_{2} \mathrm{O}-\mathrm{N} /$ year (exclusive the contribution from combustion of fossil fuel, calculated from data in Pérez-Ramírez, 2002). Based on this figure it can be calculated that from the global annual production of nitrogen fertiliser of 90 Mton $\mathrm{N}$ about $0.3 \%$ will dissipate as $\mathrm{N}_{2} \mathrm{O}$. This value is lower then the emission of $0.5-2 \%$ given by Smil (2001). It is reported (Pérez-Ramírez, 2002) that this emission largely occurs in agriculture $(50 \%)$, fertiliser production $(6 \%)$ and wastewater treatment $(21 \%)$. The emission of $\mathrm{N}_{2} \mathrm{O}$ in wastewater treatment is largely determined by operational conditions and under unfavourable conditions like high load and low COD/N

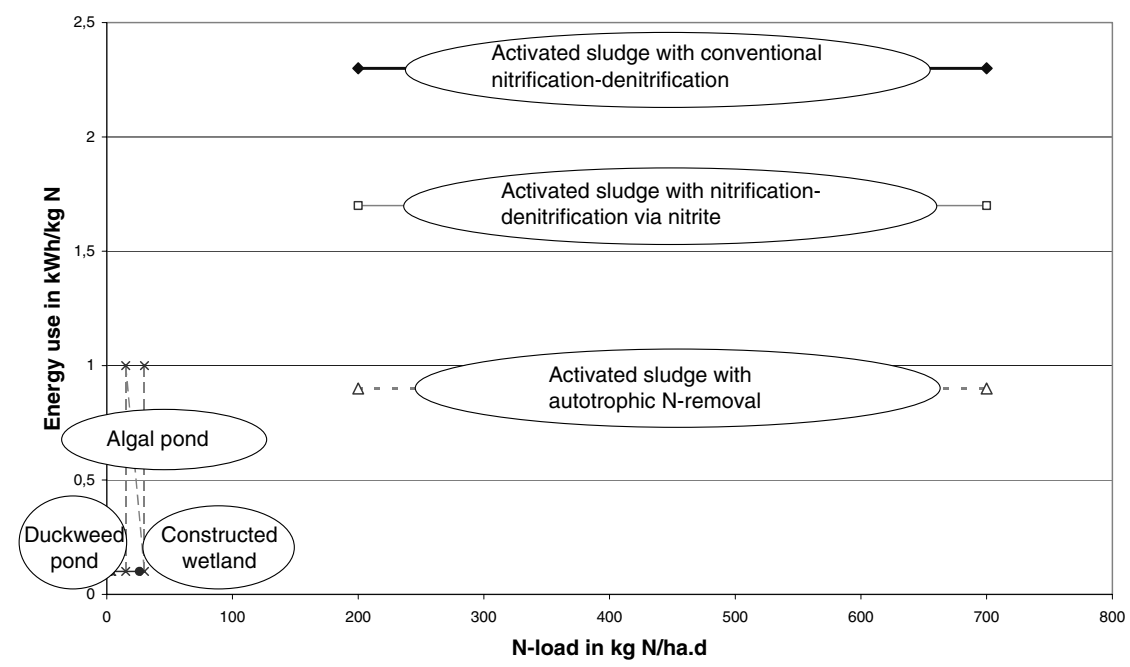

Figure 6 Comparison of energy consumption and area requirement of biological N-removal systems

Table 3 Matrix for the assessment of the sustainability of biological N-removal systems

\begin{tabular}{lcccc}
\hline N-removal system & \multicolumn{3}{c}{ Sustainability indicator } \\
& $\begin{array}{c}\text { Sludge } \\
\text { production }\end{array}$ & $\begin{array}{c}\text { Energy } \\
\text { consumption }\end{array}$ & $\begin{array}{c}\text { Resource } \\
\text { recovery }\end{array}$ & $\begin{array}{c}\text { Area } \\
\text { requirement }\end{array}$ \\
emission
\end{tabular}

1. Based on prognosis because reliable data of $\mathrm{N}_{2} \mathrm{O}$ emissions of these systems are not available 
ratio's the emission of $\mathrm{N}_{2}$ can contribute $10 \%$ in the total N-balance (Hanaki et al., 1992). In high loaded constructed wetlands the N-load is frequently much higher then the nitrogen input in intensive agriculture which is around $100 \mathrm{~kg} \mathrm{~N} / \mathrm{ha}$.year. Therefore it is likely that a considerable part of the $\mathrm{N}$-load is not taken up in plant production systems and more information is required with respect to the potential emission of nitrous oxide (Bouwman, 1998). Also the N-balances of algal and duckweed ponds must be checked for the emission of nitrous oxide.

\section{Final evaluation}

The sustainability matrix of the investigated N-removal systems show that the activated sludge system with autotrophic N-removal is the most sustainable process (Table 3 ). The next best is the duckweed pond system. The executed analysis of the nitrogen balances disclosed that on global scale there are regional imbalances with respect to $\mathrm{N}$-input and output. In regions with serious shortages in $\mathrm{N}$-input resource recovery must developed and stimulated. On the other hand it is relevant to investigate expected future developments and to anticipate expected trends. With respect to the re-use of algae and duckweed for feed production the potential risk of accumulation of metals and organic micro-pollutants must be investigated.

\section{Conclusions}

- On a global scale regional conditions with respect to N-balance, climate, development differ considerably. As a result of this there is not one universal or paramount treatment system for N-removal from sewage. Regional conditions will determine which system is optimal under given conditions of climate, agricultural, environmental and economic development. This means that in a changing world the quest for sustainable N-removal techniques will continue.

- The process of autotrophic N-removal, which combines nitrification via nitrite and anaerobic ammonium oxidation is a very sustainable process because of: the minimal energy consumption, the absence of need for organic matter for denitrification, low sludge production and high N-load. However the autotrophic N-removal systems which are currently under development are applicable for ammonium concentrations of $100-500 \mathrm{mg} \mathrm{N} / 1$. For sustainable development it is relevant to investigate the feasibility of the autotrophic $\mathrm{N}$-removal process for diluted wastewater.

- For high loaded constructed wetland systems, algal and duckweed ponds reliable data of the $\mathrm{N}$-balance and the contribution of $\mathrm{N}_{2} \mathrm{O}$-emissions are not available. This information is required for a precise assessment of the sustainability of these systems.

\section{References}

Abeling, U. and Seyfried, C.F. (1992). Anaerobic-aerobic treatment of high-strength ammonium wastewater-nitrogen removal via nitrite. Wat. Sci. Tech., 26(5-6), 1007-1015.

Alaerts, G.J., Rahman Mahbubar, M.D. and Kelderman, P. (1996). Performance analysis of a full-scale duckweed-covered sewage lagoon. Wat. Res., 30(4), 843-852.

Balmelle, B., Nguyen, K.M., Capdeville, B., Cornier, J.C. and Deguin, A. (1992). Study of factors controlling nitrite build-up in biological processes for water nitrification. Wat. Sci. Tech., 26(5-6), 1017-1025.

Bleken, M.A. and Bakken, L.R. (1997). The nitrogen cost of food production: Norwegian society. Ambio, 26(3), 134-142.

Bouwman, A.F. (1998). Nitrogen oxides and tropical agriculture. Nature, 392, 866-867.

El Hamouri, B., Jellal, J., Outabiht, H., Nebri, B., Khallayoune, K., Benkerroum, A., Hajli, A. and Firadi, R. (1995). The performance of a high-rate algal pond in the Moroccan climate. Wat. Sci. Tech., 31(12), $67-74$. 
FAO (1966-1998). Yearbook Fertiliser. Vol. 16-48, FAO, Rome.

Gijzen, H.J. and Mulder, A. (2001). The nitrogen cycle out of balance. Water21, 8, 38-40.

Gotaas, H.B. (1956). Composting: Sanitary disposal and reclamation of organic wastes. W.H.O., Geneva.

Haberl, R., Perfler, R. and Mayer, H. (1995). Constructed wetlands in Europe. Wat. Sci. Tech., 32(3), 305-315.

Hammer, D.A. and Knight, R.L. (1994). Designing constructed wetlands for nitrogen removal. Wat. Sci. Tech., 29(4), 15-27.

Hanaki, K., Hong, Z. and Matsuo, T. (1992). Production of nitrous oxide gas during denitrification of wastewater. Wat. Sci. Tech., 26(5-6), 1027-1036.

Harmsen, L.W.F., Lourens, P.A. and Van Leeuwen, H.J.M.L. (1986). Stikstofverbindingen verwijderen uit afvalwater. P.T./ Procestechniek 41, 27-29. (in Dutch).

Henze, M. (1997). Trends in advanced wastewater treatment. Wat. Sci. Tech., 35(10), 1-4.

Henze, M., Harremoës, P., La Cour Jansen, J. and Arvin, E. (1996). Wastewater Treatment: Biological and Chemical Processes. 2nd edn, Springer, Heidelberg.

Janus, H.M. and Van der Roest, H.F. (1997). Don't reject the idea of treating reject water. Wat. Sci. Tech., 35(10), 27-34.

Laegreid, M., Bockman, O.C. and Kaarstad, O. (1999). Agriculture, Fertilisers and the Environment. CABI Publishing, Wallingford, UK.

Larsen, T.A. and Guyer, W. (1996). Separate management of anthropogenic nutrient solutions (human urine). Wat. Sci. Tech., 34(3-4), 87-94.

Meuleman, A.F.M. (1999). Performance of treatment wetlands. PhD Thesis, Utrecht University.

Mulder, A., Van der Graaf, A.A., Robertson, L.A. and Kuenen, J.G. (1995). Anaerobic ammonium oxidation discovered in a denitrifying fluidized bed reactor. FEMS Microbiol. Ecology, 16, 177-184.

Oswald, W.J. (1995). Ponds in the twenty-first century. Wat. Sci. Tech., 31(12), 1-8.

Pérez-Ramírez, J. (2002). Catalyzed $\mathrm{N}_{2} \mathrm{O}$ activation: Promising (new) catalysts for abatement and utilization. PhD Thesis, Faculty of Applied Sciences, Technical University of Delft.

Polprasert, C. (1996). Organic Waste Recycling. John Wiley \& Sons Ltd., Chichester, England.

Pöpel, F. (1993). Lehrbuch für Abwassertechnik und Gewässerschutz. Deutscher Fachschriften-Verlag, Wiesbaden.

Priestley, A.J., Cooney, E., Booker, N.A. and Fraser, I. (1995). Nutrients in wastewater's - ecological problem or commercial opportunity? AWWA 17th Federal Convention, 340-346.

RIVM (1991). Nationale Milieuverkenning 1990-2010. Samson, H.D. Tjeenk Willink bv, Alphen aan den Rijn. (in Dutch).

Roeleveld, P.J., Klapwijk, A., Eggels, P.G., Rulkens, W.H. and Van Starkenburg, W. (1997). Sustainability of municipal wastewater treatment. Wat. Sci. Tech., 35(10), 221-228.

Seyfried, C.F., Rosenwinkel, K.H. and Hippen, A. (2002). Deammonification: a cost-effective treatment process for nitrogen-rich wastewater's. Proceedings WEFTECH, Chicago (in press).

Smil, V. (2001). Nitrogen and food. Papers of the Second International Nitrogen Conference, 14-18 October 2001, Washington, D.C.

Stoner, C.H. (1977). Goodbye to the flush toilet: Water-saving alternatives to cesspools, septic tanks and sewers. Rodale Press, Emmaus, PA.

Strous, M. (2000). Microbiology of anaerobic ammonium oxidation. PhD Thesis, Technical University of Delft.

Van der Graaf, J.H.J.M., Meester-Broertjes, H.A., Bruggeman, W.A. and Vles, E.J. (1997). Sustainable technological development for urban-water cycles. Wat. Sci. Tech., 35(10), 213-220.

Van Oostrom, A.J. (1995). Nitrogen removal in constructed wetlands treating nitrified meat processing effluent. Wat. Sci. Tech., 32(3), 137-147.

Wittgren, H.B. and Tobiason, S. (1995). Nitrogen removal from pre-treated wastewater in surface flow wetlands. Wat. Sci. Tech., 32(3), 69-78. 